\title{
An Empirical Study on the Impacts of the Chinese Banking Industry by Foreign Banks' Entry
}

\author{
JAE IK SEO ${ }^{1}$, Guan Shi Chao ${ }^{1} \&$ Sang-Bum Park ${ }^{1}$ \\ ${ }^{1}$ Department of Business Administration, The Graduate School, Korea Aerospace University, Korea \\ Correspondence: Sang-Bum Park, Professor, Department of Business Administration, The Graduate School, \\ Korea Aerospace University. 76 Hanggongdaehang-ro, Deogyang-gu, Goyang-city, Gyeonggi-do, 412-791, \\ Korea. E-mail: psb@kau.ac.kr
}

$\begin{array}{ll}\text { Received: October 11, } 2012 & \text { Accepted: November 15, } 2012 \quad \text { Online Published: December 10, } 2012 \\ \text { doi:10.5539/ijef.v5n1p210 } & \text { URL: http://dx.doi.org/10.5539/ijef.v5n1p210 }\end{array}$

\begin{abstract}
Foreign banks entering into the Chinese banking industry have significant influence in its profitability sources including non-interest income while foreign banks bring competitions to the domestic banking sector resulting in declined profitability of the Chinese banking industry. In addition, foreign banks' entry makes a promoting efficiency in China's banking sector. Overall foreign banks' assets become an integral part of China's financial institutions, and they may have more significant impacts on the non-traditional businesses and operational efficiency of Chinese banking which helps the formation of healthy competition.
\end{abstract}

Keywords: foreign banks' entry, Chinese banking industry, profitability

JEL Classification: $\mathrm{G} 21$

\section{Introduction}

In 1979, China approved the first foreign banks to set up offices in China. The number of foreign banks in China has begun to sprout since then. Since 1992, China has opened Xiamen, Zhuhai, Shantou, Hainan, Shanghai, for foreign banks to enter and the rapid development stage has come. The new century, China's access to the WTO, the Chinese banking industry is facing unprecedented opportunities and challenges. As the financial industry is one of the first opening areas, the rapid development of foreign banks will have a profound impact on the Chinese banking sector. Specifically, during this past decade, those aspects that whether business development by foreign banks in China has impacts on the Chinese banking industry's profitability and the operating level, and that how much are the following impacts, are our main concern. In this paper, we conduct multiple regression analysis, using the data included in the China representative four state-owned commercial banks and the related financial data about seven joint-stock banks.

\section{Research Literature Review}

In recent years, banks have to cope with foreign banks' entry into their countries. Entering other country is a new investment for foreign banks.

(1) The positive effects of foreign banks' entering into host county

In terms of the positive impact of foreign banks' entry, Gelb and Sagari (1990), Levine (1996) consider that the foreign banks entry will benefit the host county as following aspects: improving the efficiency of resource allocation; increasing the competition among banks, thereby enhancing the domestic financial service quality; accelerating the establishment of the legal framework and the banking supervision; increasing the host country's capability to procure capital from the international capital market.

(2) Empirical analysis on the impacts of the entry of foreign capital entry into the host country's banking sector

The empirical studies for the impacts by foreign banks' entering into the host banking industry carried out earlier. Most studies confirm that the foreign banks' entry leads to a positive role in improving the efficiency of the host country's financial system. Claessens, Demirgus-Kunt, Huizinga (2000) conducted a study using cross-sectional date from 80 countries, and the results show that the efficiency of the foreign banks is usually lower than domestic banks, while in developing countries the results were reversed. The increasing number and degree of foreign banks entry will break the monopoly of local banks through the competition. That also will improve bank 
profitability, reduce operating costs, improve efficient usage of resource, and promote efficiency and fairness of the entire banking industry. These results are often used as evidence that the foreign banks' entry has significant impacts in improving the overall efficiency of the banking system, and that the result is also used as a basis for developing countries to open up their financial sector. Terrel (1998) also has studied the impact of the banking industry's opening in some countries. After analyzing 14 developed countries' banking market data, he found that the countries which allow foreign banks entering usually get a lower pre-tax profit and operating costs than those do not allow to enter. In other words, the competitive effects which brought by the foreign banks will reduce the local banking market shares and profits, but it can improve the banking market functions and enhance the overall social economic level.

The representative scholars who have studies on the impacts of individual country's entry are Clarke (1999), Barajas (1999) and others. After the studies on Argentina, Colombia and Turkey and other countries, Clarke (1999) found that the foreign banks' entry will reduce the high level of the locals' operating costs, and have significant effects on improving the entire banking system efficiency. By studying how foreign banks impact on the Colombian banking industry, Barajas, Steiner (1999) found that foreign bank's entry shrinks the proliferation of intermediaries, reduces the intermediary business income and non-financial costs of the local bank at the same time, and it also lowered the cost of loans.

\section{(3) The possible adverse effects of the foreign banks' entering}

From the possible negative effects of the foreign banks' entry, Stiglitz (1993) summed up the potential risks of and costs to the domestic banking industry, enterprises and government as follow. Domestic banks will face strong technologically advanced competition from large foreign banks, thus domestic banks may suffer from the weakening of market forces and profits. Foreign banks with parent bank and subsidiaries equipped with global distribution channel will have a close business contacts with large multinational companies and provide more opportunities for the cross-sub-partnership, while the small and medium domestic enterprises may get less services for. The main purpose of foreign bank's entry is for profit. Marketing operation in the host country may weaken the role that banks do on the nation's industrial politics and the host government's macro-economic control capability. Foreign banks attract the best customer's with more advanced products and better services in the domestic market, while domestic banks may instead engage in potentially riskier businesses by the forcing competitive pressure. In addition, Agenor (2001) pointed out that once the host country faced economic difficulties, foreign banks could become a haven for social capital. Massive transferring of wealth will further exacerbate instability in the host country's financial market.

\subsection{Domestic Research Literature}

With the five-year transition period of financial opening process, foreign banks entering into China have rapidly increased from the quantity to the size. So it is increasingly important to study the impacts of foreign banks' entry into the Chinese banking industry, and proposing specific policy recommendations to face the situation is important as well. Although previous studies have accumulated wealthy experience in terms of foreign banks' entering into other countries, the most cases are for the developed countries. Because China is different from the other developed countries in some aspects, such as, the micro-economic conditions, the grades of bank opening, the financial development and so on, so the case of China should be studied with different approaches.

(1) Theoretical analysis on the impacts of foreign banks' entering into the Chinese banking industry

On the impacts of the foreign banks' entry, domestic scholars, such as, Xu Zhendong (2001), Ye Xin (2004), Guo Yan and Zhang Liguang (2005) concluded that the foreign banks' entry will help improve domestic banks' operational efficiency and financial stability. Those studies mainly reflected improving the Chinese banking efficiency by the competitive effect (Bai and Li Ya (2002) go far classification). It is undeniable that the foreign banks' entry is challenge to China, compels domestic banks to improve operational efficiency and competitiveness, and credit resources in private sector are expected to be improved. While competing and cooperating with foreign banks, the Chinese banking system, such as, risk assessment and customer credit evaluation system will be further improved. Improvement of customer credit evaluation system is expected to mend the private sector's credit resource distorted by the wrong information. The establishment of risk assessment can also reduce the risk of the entire financial system.

Also, the efficiency of resource allocation is expected to be improved (Gao Xiaohong (2000)). China has a lot of fields which hold great investment value; however, the domestic banks cannot provide financial supports to these industries, because of low level of the technology and the ability to spread the risks. So the entry of foreign banks is expected to improve the situation, digging out the huge potential and setting up competitive and effective industries. 
Foreign banks' entry will have brought forth technology spillovers in the related fields. During the process of competition and cooperation with foreign banks, domestic banks have the opportunity to learn from the foreign banks plentiful experience both in the traditional banking businesses and in the new banking businesses. In terms of technology spillover effects, domestic banks can have the opportunities to quickly grasp the advanced technology. Furthermore, a large number of Chinese staffs who served for the foreign banking institutions can acquire foreign advanced management experiences and innovative capabilities. Guo Yan and Zhang Liguang (2005) found that market competition effect, technology demonstration effect, and financial stability effect by foreign banks' are kicked in China too.

(2) The empirical analysis of the stability impact by the foreign banks' entry into the Chinese banking industry

The empirical researches analyzing the effects of the foreign banks' entering were carried out relatively later. The representatively scholars on this field are Ye Xin and Feng Zongxian (2003). They have analyzed the date of foreign banks' actual entering degrees, macroeconomic variables and financial data, and pointed out that the expansion of foreign banks entry both in number and in size help strengthen the stability of domestic banking system.

(3) The impact of other areas by the foreign banks' entering into the Chinese banking industry

Mao Zesheng (2005), Guo Yan and Zhang Liguang (2005), Huang Xian and Xiong Fuping (2006), Liu Liwei and Wu Lina (2006), Chen Weiguang and Xiao Jing (2007), also did empirical research on the efficiency effects by foreign banks' entering into the Chinese banking industry. Sun Ming (2005) studied on the impacts by foreign banks on China's regulatory sector. Liu Liwei and Wu Lina (2006) pointed out his own views on the effects of cross-border acquisitions of banks and proposed China's international banking strategy. These studies showed that foreign banks' entry may have negative effects. That is, foreign banks' entry may force Chinese domestic banks to be engaged in higher risky activities; the fierce competition for good customers could force Chinese domestic banks to transact with potential higher risky customers; foreign banks may not follow the guidelines by the government authorities of China, and its business activities may not meet the China's development strategy.

In summary, foreign banks' entry can promote the formation of inter-bank competition, consummate the overall operating efficiency of the host country's banking industry, and promote the banking management level and formation of competition among banks. But it may also weaken the domestic banks' market power and profit, reduce small and medium domestic enterprises' access to financial services, and slow down the government's macro-economic control capability. However, there is no universal answer to what impacts are brought by the foreign banks' entry. On the process of opening the financial sector, China's government should strive to bring the possible positive effects into reality, to avoid the adverse effects by foreign banks.

\section{Research Hypothesis}

\subsection{Hypothesis}

We raise the following questions: "During this past decade, business development by foreign banks in China has impacts on the Chinese banking industry's profitability, the operating level, and how much is the impacts, if any". Assuming that Chinese banking industry's profitability and operational efficiency will be impacted by the foreign bank's entry, we will measure the profitability in two aspects, the non-interest income ratio, and operational efficiency. Then we make the following assumptions:

(1) With the foreign banks' increasing operation scale, Chinese banks' net profit margin will be shrank,

(2) With the foreign banks' increasing operation scale, Chinese banks' non-interest income ratio will be reduced.

(3) With the foreign banks' increasing operation scale, Chinese banks will improve the operational efficiency.

Corresponding to the above three assumptions, we separately establish net profit margin, non-interest income, the ratio of operating costs to total costs (operating efficiency), which are the explanatory variables for the three models. In the three models, an independent variable, foreign banks' business in China (the ratio of foreign banks' assets to China's financial institutions (FAP)), is included.

\subsection{Variables}

In order to answer whether foreign banks' entry has effects on profitability of China's banking industry, we first need to select proxy variables which represent the profitability of the banking industry. Here we consider two variables, net profit margin (NP) and non-interest income ratio (NNIR). Net profit margin is the net profit divided by total assets, while non-interest income ratio is non-interest operating income divided by the sum of net interest income and non-interest income. The reason we use net profit margin (NP) is because it mainly reflects the bank's overall profitability. Considering that the deposit and loan spreads are the major part of 
Chinese banking income, we take the NNIR to measure the non-traditional income profitability of the Chinese banking industry. Similarly, to answer whether the foreign banks impact on the operation efficiency of China's banking, we select a proxy for the efficiency of banking operations. Before and after the foreign banks' entry, the sample banks' operating costs (OC) can be different, so the change in operating costs can be to some extent reflect the impacts by foreign banks' entry to the operating efficiency of sample banks. But each sample bank has different asset size and different operating cost size, so we choose the ratio of operating costs (OC) to the total cost $(\mathrm{TC}), \mathrm{OE}(\mathrm{OE}=\mathrm{OC} / \mathrm{TC}))$, as a proxy variable, to eliminate the effect of the sample bank size.

In the current literature, there are two methods to measure the degrees of foreign banks' entry. The first is the number of foreign banks, the ratio of the number of foreign banks to the number of domestic banks. The second is the share of assets owned by foreign banks, the total foreign bank assets proportional to the total domestic banking assets. Although the total assets of China's banking industry is huge but highly concentrated in the market, that is, the number of banks in China is small, coupled with restrictions on foreign banks business scope, the foreign banks that have some market share can bring impacts on making prices and profits of domestic banks. According to the fact that Chinese actual conditions are more in line with the second measure, we choose the total assets of foreign banks proportional to those of Chinese financial institutions as the proxy variables of the degree of the foreign banks entry.

Here are the control variables. The rate of inflation (CPI) can affect the Chinese banking industry profitability and operational efficiency. And other variables included are total assets (TA), operating income (OR), and the total cost (TC).

\subsection{Sample Selection}

We selected four state-owned China's commercial banks, China Construction Bank, Agricultural Bank of China, Bank of China and Commercial Bank of China, and seven joint-stock banks, Merchants Bank, CITIC Bank, Bank of Communications, Shanghai Pudong Development Bank, Industrial Bank, Huaxia Bank and Minsheng Bank. The time period for the sample is the last decade, from 1999 to 2008. The data were collected from the "China Financial Yearbook"(Volume 2009 to Volume 2000) and "China Statistical Yearbook" (Volume 2009 to Volume 2000).

\subsection{Sample Statistical Analysis}

Here we will do the appropriate statistical description of the selected 11 banks on three selected variables: net profit margin (NP), ratio of non-interest income to operating income (NIOI), and ratio of operating costs to total cost $\mathrm{OE}(\mathrm{OE}=\mathrm{OC} / \mathrm{TC})$, to make understand further on their basic features.

Table 1. Sample bank's descriptive statistics on net interest (1999-2008)

\begin{tabular}{lllll}
\hline bank & Mean value & Stand. deviation & Max. value & Min. value \\
\hline Agricultural Bank of China & 0.001818 & 0.002891 & 0.007357 & -0.000155987 \\
Bank of Communications & 0.005078 & 0.003356 & 0.010589 & 0.000803594 \\
Bank of China & 0.006192 & 0.004022 & 0.012707 & 0.001111115 \\
China Construction Bank & 0.006886 & 0.004474 & 0.012542 & 0.001395955 \\
Industrial Bank & 0.005344 & 0.003225 & 0.011152 & 0.000934689 \\
China Minsheng Bank & 0.010241 & 0.015806 & 0.055081 & 0.003621879 \\
China Merchants Bank & 0.006726 & 0.003152 & 0.013326 & 0.004425543 \\
China CITIC Bank & 0.005366 & 0.002473 & 0.011214 & 0.003145847 \\
Bank of China & 0.004625 & 0.001918 & 0.008375 & 0.003249213 \\
ICBC & 0.00388 & 0.004061 & 0.011432 & 0.000407546 \\
Pudong Development Bank & 0.010374 & 0.014446 & 0.051186 & 0.004220376 \\
\hline
\end{tabular}

We can see from the table 1, Minsheng Bank, Shanghai Pudong Development Bank have high total capital utilization, more than $1 \%$ net profit margin. Of course, the result has relationship with lesser total assets. In contrast, the Agricultural Bank of China and Commercial Bank of China's have relatively low total capital utilization, only $0.182 \%$ and 0.38806 , respectively, which may have the relationship with their own enormous assets. 
Table 2. The Descriptive statistics of sample banks' ratio of non-interest income to operating income (1999-2008)

\begin{tabular}{lllll}
\hline bank & Mean value & Stand. deviation & Max. value & Min. value \\
\hline Agricultural Bank of China & 0.2982 & 0.21673 & 0.60037 & 0.08219 \\
Bank of Communications & 0.47364 & 0.31594 & 0.81006 & 0.08413 \\
Bank of China & 0.23697 & 0.06502 & 0.33897 & 0.13833 \\
China Construction Bank & 0.2732 & 0.22312 & 0.71983 & 0.06345 \\
Industrial Bank & 0.37949 & 0.28915 & 0.81797 & 0.02892 \\
China Minsheng Bank & 0.42821 & 0.29243 & 0.71798 & 0.04868 \\
China Merchants Bank & 0.425 & 0.19454 & 0.66209 & 0.15714 \\
China CITIC Bank & 0.49636 & 0.30173 & 0.78797 & 0.05992 \\
Bank of China & 0.4035 & 0.23746 & 0.70788 & 0.04416 \\
ICBC & 0.2373 & 0.29578 & 0.8236 & 0.05437 \\
Pudong Development Bank & 0.37889 & 0.29115 & 0.76324 & 0.0218 \\
\hline
\end{tabular}

We can see from the Table 2 that different banks have different ratio of non-interest income to operating income. That indicates different banks have different non-traditional business development. For the ratio of non-interest income to operating income among banks of table, Merchants Bank, CITIC Bank, and China Minsheng Bank exceed $40 \%$. While the four state-owned commercial banks, Agricultural Bank of China, Bank of China, China Construction Bank, China Industrial and Commercial Bank were only 29.82\%, 23.6970\%, 27.32\% and 23.73\%. This fact reveals that the four major commercial banks earn the main income from traditional deposits and loan businesses. But among the banks listed above, CITIC Bank, Huaxia Bank, and Minsheng Bank are actively expanding their non-traditional businesses, to be more flexible on the way of the operation.

Table 3. Descriptive statistics of the sample banks' ratio of the operating costs to the total cost (1999-2008)

\begin{tabular}{lllll}
\hline Bank & Mean value & Stand. deviation & Max. value & Mini. value \\
\hline Agricultural Bank of China & 0.82871 & 0.2952 & 0.9201 & 0.42808 \\
Bank of Communications & 0.61343 & 0.3468 & 0.7406 & 0.3372 \\
Bank of China & 0.79392 & 0.3093 & 0.8816 & 0.41796 \\
China Construction Bank & 0.81888 & 0.2747 & 0.9186 & 0.46062 \\
Industrial Bank & 0.54031 & 0.3699 & 0.7308 & 0.32644 \\
China Minsheng Bank & 0.54794 & 0.3765 & 0.6414 & 0.31987 \\
China Merchants Bank & 0.66101 & 0.3495 & 0.8246 & 0.37526 \\
China CITIC Bank & 0.49359 & 0.3969 & 0.8399 & 0.33765 \\
Bank of China & 0.46225 & 0.4322 & 0.7663 & 0.31309 \\
ICBC & 0.83228 & 0.2606 & 0.8917 & 0.42522 \\
Pudong Development Bank & 0.41483 & 0.3882 & 0.7412 & 0.30728 \\
\hline
\end{tabular}

We can see from the table 3, the four major commercial banks and the joint-stock banks have relatively larger operating costs ratio. The four major commercial banks have generally relatively high, while the joint-stock banks are low. We mainly want to examine the net profit rate (NP), the non-interest income ratio (NNIR) and the ratio of operating costs to the total cost $(\mathrm{OE} ; \mathrm{OE}=\mathrm{OC} / \mathrm{TC})$ to see whether the three variables affected by the impact of foreign bank entry.

From the correlation analysis, we can see that net profit rate (NP), non-interest income accounted for the ratio of operating income (NNIR) and the operating costs of the total cost ratio OE have a significant correlation with the foreign banks entry. Pearson correlations are $0.4368,-0.60585$ and 0.25439 , respectively, while $\mathrm{P}$ values of the three Pearson correlation coefficients are less than $5 \%$. That is, the three research variables and the assets of foreign banks were significantly related.

\subsection{Regression Models}

According to the three hypotheses in section 3.1, we set up multiple regression models for the three variables.

We conduct multiple linear regressions on samples (11 banks) from the data of 2008 to 1999, using generalized linear least squares estimation method, model parameters screening methods using stepwise regression method. 
(1) The final model parameter estimation and the final model equations are as follows:

From the perspective of the sample banks net profit margin, we examine the impacts by the foreign banks' entering on the profitability of China's banking industry. The model is:

$$
N P=\alpha_{0}+\alpha_{1} F A P+\alpha_{2} O R+\alpha_{3} T A+\varepsilon
$$

(2) For the analysis of the effects of non-interest income ratio, the model is:

$$
N N I R=\alpha_{0}+\alpha_{1} F A P+\alpha_{2} O R+\alpha_{3} T A+\varepsilon
$$

(3) For the analysis of the impacts on operating efficiency, the model is:

$$
O E=\alpha_{0}+\alpha_{1} F A P+\alpha_{2} T C+\varepsilon
$$

\begin{tabular}{|c|c|c|c|c|c|c|c|c|c|}
\hline & Model 1 & & & Model 2 & & & Model 3 & & \\
\hline Variable & $\begin{array}{l}\text { Parameter } \\
\text { estimation }\end{array}$ & $\mathrm{t}$ value & $\mathrm{p}$ value & $\begin{array}{l}\text { Parameter } \\
\text { estimation }\end{array}$ & $\mathrm{t}$ value & $\mathrm{p}$ value & $\begin{array}{l}\text { Parameter } \\
\text { estimation }\end{array}$ & $\mathrm{t}$ value & $\mathrm{p}$ value \\
\hline Intercept & -0.00842 & -1.64 & 0.1066 & 1.16467 & -.14 & $<.0001$ & -5.73658 & -1.56 & 0.1243 \\
\hline FAP & -0.00791 & -3.02 & 0.0037 & -0.45089 & -6.95 & $<.0001$ & 5.47506 & 2.94 & 0.0046 \\
\hline OR & 0.0000111 & 3.2 & 0.0021 & 0.0003093 & 3.61 & 0.0006 & - & & \\
\hline $\mathrm{TA}$ & $-3.15 \mathrm{E}-07$ & -3.19 & 0.0022 & $-1.01 \mathrm{E}-05$ & -4.13 & 0.0001 & - & & \\
\hline $\mathrm{TC}$ & - & & & - & & & -0.00493 & -3.83 & 0.0003 \\
\hline $\begin{array}{l}\text { Adj. } \\
\text { R-sqaure }\end{array}$ & 0.2737 & & & 0.4912 & & & 0.2174 & & \\
\hline
\end{tabular}

The results are summarized as the following table.

Table 4. Empirical results of

\section{Conclusion}

We can conclude from the above results: We can see that the coefficient of the total foreign bank assets proportional to the total domestic banking assets is negative at $5 \%$ significance level. Negative coefficient indicates that foreign banks in China impact the banking industry's net profit margin negatively. As the assets of foreign banks expand, their impacts cause significant conflicts with domestic banking sector. As the foreign banks increase volume of business in the host country, the domestic bank's net profit rate decreased significantly. The coefficient of operating income is significantly positive, which is consistent with and relevant to the financial theories indicating that the more operating income, the greater net profit margin. But it is worth notifying that the total assets coefficient is significantly negative, which shows that the larger of the sample bank's total assets, the lower net profit rate is. And this is the same as we saw from the general statistical description before. It is shown that to some sample banks, the larger of the asset size, the more administrative costs, the more difficult to manage, even the net profit margin may decline with the increase of sample banks assets. We should pay attention to such phenomenon.

We can see if we divide the net profit into interest income and noninterest income, the non-interest income estimated coefficient is also significantly negative in the final model. Similarly, foreign banks' entry did insignificant impacts on Chinese non-traditional businesses. Because Chinese interest rates are not market-oriented interests, and Chinese bank deposits and lending rates are determined under the guidance of the government regulations, the ratio of interest income to operating income is very small due to the fact that the major part of Chinese major banks' income is their deposits and loans spread. Compared to domestic banks, foreign banks do not have advantages in the size of deposits but they have advantage in loan interest rates. That may lead to negative impacts on Chines banks' non-traditional businesses and financial services. With the increasing scale of foreign banks, domestic banking businesses for the income from non-traditional business will become lesser. The operating income coefficient is significantly positive, indicating that the more operating income, the greater ratio of non-interest income to operating income. The fact that the coefficient of total assets is significantly negative shows that the greater the total assets of sample banks, the smaller ratio of non-interest income ratio.

From the perspective of operational efficiency, the result that coefficient of the ratio of the total foreign banks' assets to those of Chinese financial institutions is positive indicates that there is significant improvement in operating efficiency by foreign banks' entry, which is the same to our theoretical analysis. In addition, the total 
costs have significant effect on operating efficiency, that is, the lower total cost, the better operational efficiency.

On the whole, foreign banks entering into the Chinese banking industry have significant influence in its profitability including some non-interest income. In addition, foreign banks' entry impacts significantly on the bank's operational efficiency. On one hand, foreign banks bring competitions to the domestic banking sector resulting in declined profitability of the Chinese banking industry. On the other hand, due to competition, foreign banks' entry makes promoting efficiency in China's banking sector. Until foreign banks' overall assets become an integral part of China's financial system, it may bring more significant impacts on the non-traditional businesses and operational efficiency of the Chinese banking system which helps the formation of healthy competition.

\section{References}

Aliber, Robert. Z. (1984). International Banking: a survey. Journal of Money, Credit. http://dx.doi.org/10.2307/1992100

Gelb, \& Sagari, (1990). Trade in banking service: Issues for multinational negotiation, Financial Systems and Policy Division, Country Economics Dept. World Bank.

Levine, R. (1996). Financial development and economic growth: views and agenda. Policy Research Working Paper Series 1678. The World Bank.

Claessens, S., Demirguc-Kunt, A., \& Huizinga, H. (1998). How Does Foreign Entry Affect the Domestic Banking Market?. Working Paper. World Bank.

Classens, S., Demirguc-kunt, A., \& Huizinga, H. (2001). How does foreign entry affect domestic banking markets?. Journal of Banking and Finance. http://dx.doi.org/10.1016/S0378-4266(00)00102-3

Terrell, H. S. (1986). The role of foreign banks in domestic banking markets, in H.Cheng, ed., Financial Policy and Reform in Pacific-Rim Countries. Lexington: Lexington Books.

Clarke, George. (2002). Bank Lending to Small Businesses in Latin America: Does Bank Origin Matter? World Bank Policy Research Working Paper No. 2760.

Barajas, A., \& Steiner, R. (2002). Why Don't They Lend? Credit Stagnation in Latin America. IMF Staff Papers, 49, 156-184.

Barajas, A., Steiner, R., \& Salazar, N. (1999). Interest Spreads in Banking in Colombia.

Stiglitz, J. E. (1993). The Role of the State in Financial Markets. Proceedings of the World Bank Annual Conference on Development Economics. IMF Staff Papers, 46(2), 196-225.

Pierre-Richard Agénor. (2001). Monetary Policy under Flexible Exchange Rates: An Introduction to Inflation Targeting, Central Bank of Chile, Working Papers, No 124, Noviembre.

Guo, Yan, \& Zhang, Liguang. (2004). Measuring Opening Degree of Chinese Economy and the Experimental Analysis of Relationship with Economic Growth. Statistical Research, 4.

$\mathrm{Xu}$, Zhendong. (2001). The open banking of Developing countries financial effect analysis. The Journal of World Economy.

Ye, Xin. (2004). The entry of foreign banks' influence and effect on Chinese banking industry. Modern Commercial Banking.

Guo, Yan, \& Zhang, Liguang. (2005). The entry of foreign banks' impact on Chinese banking industry empirical analysis. Economic Science.

Bai, Xuya, \& Li, yan. (2002). The entry of foreign banks is helpful to break the inefficient balance of the bank of China. Journal of Capital University of Economics and Business.

Gao, Xiaohong. (2000). The entry of foreign banks and Chinese commercial bank reform and problem solving. Journal of Financial Research.

Ye, Xin, \& Feng, Zongxian. (2004). The entry of foreign banks' effect on the stability of the Chinese banking system. The Journal of World Economy.

Mao, Zesheng. (2005). The entry of foreign banks' impact on Chinese banking industry empirical study. Journal of Nanjing Normal University.

Huang, Xian, \& Xiong, Fuping. (2004). Foreign banks in China operating motivation and strategy analysis. Journal of Financial Research.

Liu, Liwei, \& Wu, Lina. (2006). The entry of foreign banks' causes and the effect on Chinese banking industry 
empirical analysis. Statistics and Decision.

Chen, Weiguang, \& Xiao, Jing. (2007). Empirical Study on the effect of foreign bank entry. Economist.

Sun, Ming. (2005). Intervention of multinational banks' impact and regulation on developing countries. Contemporary Economics. 